\title{
OPEM
}

www.opem.org

Oriental Pharmacy and Experimental Medicine 2010 10(2), 111-115

DOI 10.3742/OPEM.2010.10.2.111

\section{Hepatoprotective activity of Nyctanthes arbor-tristis (l.)}

\author{
Wagh AE, Yeotkar US, Nimbhorker MG, Deshmukh TA* and Patil VR \\ Department of Pharmacognosy, Tapi Valley Education Society's Hon'ble, Loksevak Madhukarrao Chaudhari \\ College of Pharmacy, North Maharashtra University, Faizpur-425 503, Maharashtra, India
}

Received for publication November 13, 2009; accepted April 28, 2010

\begin{abstract}
SUMMARY
The flowers of Nyctanthes arbor-tristis Linn. of Oleaceae widely used in Ayurvedic system of medicine for the treatment of diuresis, liver disorder, spleen enlargement sciatica, bitter, stomachic, carminative and tonic to hair. The aim of the present study was to evaluate the alcoholic and aqueous extracts of the flowers of Nyctanthes arbor-tristis for hepatoprotective effect against carbontetrachloride induced liver damage in rats. Administration of alcoholic and aqueous extracts of the leaves of Nyctanthes arbor-tristis protect the liver from toxic effects of carbontetrachloride by reducing the elevated levels of Serum glutamate pyruvate transaminase, Serum glutamate oxaloacetate transaminase, Alkaline phosphatase and serum bilirubin. Results revealed that both the alcoholic and aqueous extracts showed significant hepatoprotective activity by reducing the elevated levels of biochemical parameters at a dose of $200 \mathrm{mg} / \mathrm{kg}$ body weight. The results were supported by histopathological studies of liver samples which showed regeneration of hepatocytes by the extracts.
\end{abstract}

Key words: Nyctanthes arbor-tristis; Carbon tetrachloride; Hepatoprotective

\section{INTRODUCTION}

Liver plays a major role in detoxification and excretion of many endogenous and exogenous compounds, any injury to it or impairment to its functions may lead to many implications on one's health. Management of liver disease is still a challenge to the modern medicine (Handa, 1991; Reddy et al., 1993). Modern medicine has little to offer alleviation of hepatic ailments; where as most important representatives are of phytoconstituents.

\footnotetext{
*Correspondence: Deshmukh TA, Department of Pharmacognosy, Tapi Valley Education Society's Hon'ble, Loksevak Madhukarrao Chaudhari College of Pharmacy, North Maharashtra University, Faizpur425 503, Maharashtra, India. Tel: +02585245574; Fax: +02585245574; E-mail: deshmukhta@rediffmail.com
}

Nyctanthes arbor-tristis Linn. is a large shrub which is widely cultivated throughout India as a garden plant. It is claimed that almost all parts of this plant is useful in cardiovascular, liver and spleen disorders (Antonov and Malchevski, 1980). The bitter leaves are used in traditional system of medicine for the treatment of rheumatism, sciatica and intestinal worms. The powdered seeds are recommended for the treatment of scurvy (Basu and Kirtikar, 1995; Yoganarasimhan, 1996; Anonymous, 2001). The plant has been reported to possess hepatoprotective (Hukkeri et al., 2006) antibacterial activity (Ganjewala and Priya, 2007) antioxidant activity (Dasgupta and De, 2006) and anti-inflammatory activity (Amrite et al., 2006).

The preliminary phytochemical studies indicated presence of alkaloids, tannins, carbohydrates, 
triterpenoids, glycosides and flavoinoids in the flowers of Nyctanthes arbor-tristis Linn. 3, 3a, 7, 7atetrahydro-3a-hydroxy- $6(2 \mathrm{H})$-benzofuranone, $\beta$ sitosterol and stigmasterol were isolated from the flowers of Nyctanthes arbor-tristis Linn. (Khatune et al., 2005). Ethanol extract from the flowers of Nyctanthes arbor-tristis led to the isolation of cyclohexylethanoid, rengyolone: a new iridoid glucoside, 6-o-trans-cinnamoyl-7-o-acetyl-6b-hydroxyloganine and three known iridoid glucoside, arborside $-\mathrm{C}$, 6b-hydroxyloganine and nyctanthoside (Pittaya et al., 2003). In this study an attempt was made to provide scientific backing to the traditional claims. We therefore evaluated the hepatoprotective activity, of Nyctanthes arbor-tristis.

\section{MATERIALS AND METHODS}

\section{Plant material}

Flowers of Nyctanthes arbor-tristis Linn. were collected from the local area of Malkapur, Dist. Buldhana, Maharashtra, India and were authenticated at the Botanical Survey of India, Pune. The specimen was preserved in the Herbarium section of the department (Voucher No. wanapl-1).

\section{Extraction and preparation of test sample}

The flowers of Nyctanthes arbor-tristis Linn were shade dried and pulverized. The coarse powder $(1,000 \mathrm{~g})$ was extracted with ethanol using a soxhlet apparatus. Finally, the aqueous extract was prepared by maceration for one week and the extract was concentrated in dark under reduced pressure. The extracts were dried using a rotary vacuum evaporator and stored in an amber coloured bottle in refrigerator. The percentage yield of ethanol and aqueous extracts was 12.57 and 20.00 respectively.

\section{Phytochemical screening}

Ethanol and aqueous extract were screened qualitatively for various constituents like alkaloids, steroids, flavonoids, saponins, reducing sugars, carotenoid, tannins and anthraquinones using established methods (Khandelwal, 2002).

\section{Animals}

Wistar albino rats (150 - $200 \mathrm{~g})$ and mice $(20$ - $25 \mathrm{~g})$ of either sex were purchased from Calcutta Fish Aquarium, Indore, India and were housed under standard conditions of temperature and light. Animals had free access to food (Amrut Feeds, Pune, India) and water. The Institutional Animal Ethics Committee approved the protocol of the study.

\section{Chemicals}

All solvents for extraction (S. D. Fine Chem. Ltd, India), Liv-52 syrup Himalaya Drug Company, Bangalore), $\mathrm{CCl}_{4}$ (Loba Chem. Ltd. India), SGOT and SGPT kit (Transasia Bio-Medicals Ltd. Daman), ALP kit (Reckon Diagnostics Pvt. Ltd. Baroda), Serum Bilirubin kit (Siemens Medical Solution Diagnostics Ltd. Baroda) were purchased from respective vendors.

\section{Acute toxicity studies}

Healthy adult Swiss albino mice of either sex weighing between 20 to $25 \mathrm{~g}$ were subjected to acute toxicity studies as per guidelines (AOT no. 425) suggested by the Organization for Economic Cooperation and Development (OECD, 1998). The mice were observed continuously for $2 \mathrm{~h}$ for behavioral, neurological and autonomic profiles for any lethality or death for the next $48 \mathrm{~h}$.

\section{Evaluation of hepatoprotective activity}

Hepatoprotective activity was carried out using Wistar albino rats $(150-200 \mathrm{~g})$ of either sex. The animals were divided in to five groups of six animals each and maintained on standard diet and water, ad libitum. Distilled water $(10 \mathrm{ml} / \mathrm{kg})$ was given to groups I and II as a vehicle for 10 days by oral route. Liv-52 was administered to group III at the dose of $1 \mathrm{ml}$ per $\mathrm{kg}$ body weight by oral route for 10 days. Ethanol and aqueous extracts were administered to groups IV and $\mathrm{V}$, respectively at a dose of $200 \mathrm{mg} / \mathrm{kg}$ by oral route for 10 days. $\mathrm{CCl}_{4}$ 
at a dose of $0.7 \mathrm{ml}$ per $\mathrm{kg}$ body weight was injected to animals of groups II, III, IV and V on 3rd, 6th and 10th day by intraperitonial route. On 10th day, $1 \mathrm{~h}$ after the last dose of Carbon tetrachloride injection, animals were sacrificed by cervical dislocation and the blood was collected from the carotid artery, serum was separated and used for the estimation of various biochemical parameters.

Biochemical parameters (Chandrasekhar et al., 2004) such as serum glutamate oxaloacetate transaminase, serum glutamate pyruvate transaminase, alkaline phosphatase (ALP) and serum bilirubin were determined. Liver was excised quickly fixed in $10 \%$ formalin and then fixed in bovine solution, they were processed for paraffin embedding following the standard micro technique. Sections of liver were stained with haematoxylin-eosin and were observed microscopically for any histopathological changes.

\section{Statistical Analysis:}

All values are expressed as mean \pm SEM. Statistical analysis were performed by one-way Analysis of Variance (ANOVA) and individual comparisons of the group mean values were done using Dunnet's $t$-test, with the help of Graph Pad prism 4.0 software. The value of $P$ lower than 0.05 were considered as significant (P is probability) (Dunnet, 1964; Osel et al., 1975).

\section{RESULTS}

\section{Phytochemical studies}

The preliminary phytochemical studies indicated presence of alkaloids, tannins, carbohydrates, triterpenoids, glycosides and flavonoids in the flowers of Nyctanthes arbor-tristis Linn.

\section{Acute toxicity studies}

In acute oral toxicity study, Nyctanthes arbor-tristis Linn. was safe upto a dose level of $200 \mathrm{mg} / \mathrm{kg}$ of body weight. No lethality or any toxic reactions were found upto the end of the study period.

\section{Evaluation of hepatoprotective activity}

The results of biochemical parameters revealed the elevation of enzyme level in $\mathrm{CCl}_{4}$ treated group, indicating that $\mathrm{CCl}_{4}$ induces damage to the liver (Table 1). A significant reduction $(P<0.01)$ was observed in SGPT, SGOT, ALP and total bilirubin levels in the groups treated with Liv 52, ethanol extract and aqueous extract of Nyctanthes arbortristis. The enzyme levels were almost restored to the normal. It was found that the extract decreased the $\mathrm{CCl}_{4}$ induced elevated levels of the enzymes in drug treated groups, indicating the production of structural integrity of hepatocytic cell membrane or regeneration of damaged liver cells by the extract.

Histopathological examination of the liver section of the rats treated with toxicant showed intense centrilobular necrosis and vacuolization. The rats treated with Liv 52 and extracts along with toxicant showed sign of protection against these toxicants to considerable extent as evident from formation of normal hepatic cards and absence of necrosis and vacuoles. Decrease in serum bilirubin after treatment with the extract in liver damage indicated the

Table 1. Effect of Nyctanthes arbor-tristis flowers on SGOT, SGPT, ALP and Total Bilirubin in $\mathrm{CCl}_{4}$ induced hepatotoxic rats

\begin{tabular}{lcccc}
\hline Group & SGOT (IU/L) & SGPT (IU $/ \mathrm{L})$ & ALP $(\mathrm{IU} / \mathrm{L})$ & Total Bilirubin $(\mathrm{mg} / \mathrm{dl})$ \\
\hline Control $(10 \mathrm{ml} / \mathrm{kg})$ & $46.33 \pm 3.46$ & $41.33 \pm 3.2$ & $124.66 \pm 1.5$ & $0.775 \pm 0.03$ \\
CCl $_{4}(0.7 \mathrm{ml} / \mathrm{kg})$ & $230 \pm 46.55$ & $230 \pm 36.16$ & $180.16 \pm 4.8$ & $1.25 \pm 0.01$ \\
Liv $52(1 \mathrm{ml} / \mathrm{kg})$ & $77.16 \pm 10.3^{* *}$ & $56.5 \pm 1.76^{* *}$ & $119.6 \pm 7.5^{* *}$ & $0.87 \pm 0.02^{* *}$ \\
Ethanol Extract $(200 \mathrm{mg} / \mathrm{kg})$ & $54.16 \pm 2.42^{* *}$ & $45.33 \pm 1.17^{* *}$ & $141.5 \pm 3.1^{* *}$ & $0.78 \pm 0.01^{* *}$ \\
Aqueous Extract $(200 \mathrm{mg} / \mathrm{kg})$ & $47.33 \pm 1.38^{* *}$ & $44.16 \pm 1.07^{* *}$ & $160 \pm 5.5^{*}$ & $0.68 \pm 0.068^{* *}$ \\
\hline
\end{tabular}

Results are expressed as mean S.D, ANOVA followed by Dunnett ' $t$ ' test. ${ }^{*} P<0.05$ and ${ }^{* *} P<0.01$. 


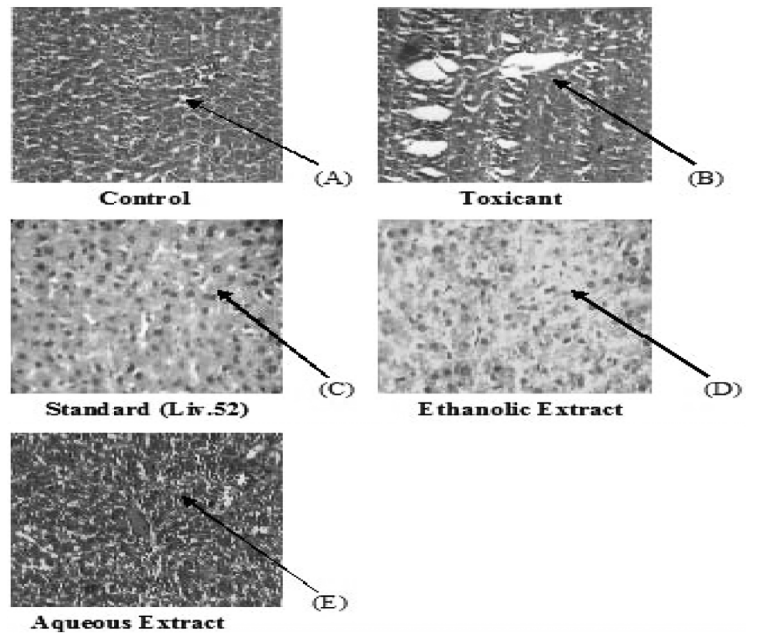

Fig. 1. Histopathological data of Liver Tissue on Rats. Wagh AE, Yeotkar US, Nimbhorker MG, Deshmukh TA, Patil VR.

(A)- Hepatocytes showing normal physiology. (B)Liver tissue showed severe necrosis and moderate fibrosis changes. (C)- No centriolobular necrosis, hepatocytes showing regenerative activity. (D)- Less fatty changes with moderate necrosis and regenerative activity. (E)- Less necrosis and showed regenerative activity of the liver.

effectiveness of the extract in normal functional status of the liver (Fig. 1).

\section{DISCUSSION}

$\mathrm{CCl}_{4}$ is one of the most commonly used hepatotoxin in the experimental study of liver diseases (Johnson and Kroening, 1988). The toxicity produced by $\mathrm{CCl}_{4}$ is due to the reaction of free radicals $\left(\cdot \mathrm{CCl}_{3}\right.$ or $\mathrm{CCl}_{3} \mathrm{COO}$ ) with lipids and proteins and with various tissue constituents. The free radical causes the peroxidation of the poly-enoic lipids of the endoplasmic reticulum and generation of secondary free radicals derived from these lipids, a chain reaction. This destructive lipid per oxidation leads to breakdown of membrane structure and function; as a result there is elevation of enzyme levels in plasma (Gautam et al., 2007).

Ethanol extract has significantly reduced these liver enzyme levels, which indicates hepatoprotection.
Furthermore, results of hepatocellular damage caused by $\mathrm{CCl}_{4}$ and its recovery by ethanol extract suggest that the drug might be considered a potential source of natural hepatoprotective agents, which could be related to free radical scavenging properties of flavonoides present in the ethanol extract of the plant.

Histopathological sections of negative group showed normal cellular architecture with distinct hepatic cells, sinusoidal spaces and central vein. Disarrangement of normal hepatic cells with centrilobular necrosis vacuolization of cytoplasm and fatty degeneration were observed in carbon tetrachloride intoxicated rats. The liver sections of the rats treated with the extracts of Nyctanthes arbor-tristis at dose of $200 \mathrm{mg} / \mathrm{kg}$ followed by carbon tetrachloride intoxication exhibited a significant protection as it was evident by the absence of necrosis, tissue damage and vacuoles.

All these parameters conforming the protective potential of ethanol extract against carbon tetrachloride induced hepatotoxicity (Devi et al., 2000). A possible mechanism of Nyctanthes arbortristis ethanol extract as hepatoprotective may be due to its antioxidant effect which impairs the activation of carbon tetrachloride into the reactive form. Since flavonoides have hepatoprotective activities (Orhan et al., 2007). Tannins and carotenoids, both are known to be antioxidants with and hepatotoxic activity (Sasmal et al., 2007). It may be speculated that the constituents of Nyctanthes arbor-tristis especially the flavonoids, tannins and carotenoids were responsible for the observed protective effects.

Based on the present findings, it can be concluded that the probable mechanism by which the Nyctanthes arbor-tristis Linn flowers exerts its protective action against $\mathrm{CCl}_{4}$-induced hepatocellular metabolic alterations could be by the stimulation of hepatic regeneration through an improved synthesis of proteins, or due to its ability to block the bioactivation of $\mathrm{CCl}_{4}$ by inhibiting the P 450 2E1 activity and/or its accelerated detoxification and 
the potential to minimise the deleterious effects of free radicals including the peroxide radicals and its antioxidant activity in combination with the inhibition of lipid peroxidation, thereby the Nyctanthes arbor-tristis Linn leaves can be ranked as hepatoprotective agent by the combined synergistic effect of its constituents and micronutrients rather than to any single factor through free radicals scavenging activity. Further work is going on to isolate the active components, which are responsible for hepatoprotection.

\section{REFERENCES}

Amrite O, Thurackal J, Gadgoli C. (2006) Evaluation of anti-inflammatory activity of Nyctanthes arbortristis Linn. and Onosma echoides. P'cog. Mag. 2, 258260.

Anonymous. (2001) The Wealth of India, A Dictionary of Indian Raw Materials and Industrial Products, Vol. VII. pp. 69, New Delhi Publication and Information Director, CSIR, New Delhi.

Antonov S, Malchevski M. (1980) Changes in the activity and properties of ALP isoenzymes in the blood serum of sheep with experimentally damaged livers. Med. Nauki. 17, 52-57.

Chandrashekhar VM, Abdul Haseeb TS, Habbu PV, Nagappa AN. (2004) Hepatoprotective activity of Wrightia tinctoria (Roxb) in rat. Indian Drugs 41, 366.

Dasgupta N, De B. (2006) Antioxidant activity of some leafy vegetable of India, A comparative study. J. Food Chemistry 101, 471-474.

Devi GS, Prasad MH, Saraswathi I, Raghu D, Rao DN, Reddy PP. (2000) Free radical antioxidant enzymes and lipid peroxidation in different types of lukemias. Clin. Chim. Acta 293, 53-62.

Dunnet CW. (1964) New tables for multiple comparisons with a control. Biometrics 20, 482-491.

Gautam SP, Ganjiwale RO, Yeole PG. (2007) Hepatoprotective activity of Tecomella undulata leaves. Int. J. Green Pharm. 1, 24-27.

Handa SS. (1991) Management of hepatic ailment. Pharma times 23, 13.

Hukkeri VI, Akki KS, Sureban RR, Gopalakrishna B,
Byahatti VV. (2006) Diuretic activity of the leaves of Nyctanthes arbor-tristis Linn. Indian Drugs 43, 148149.

Johnson DE, Kroening C. (1988) Mechanism of early carbon tetrachloride toxicity in cultured rat hepatocytes. Pharmacol. Toxicol. 83, 231-239.

Khandelwal KR. (2002) Practical Pharmacognosy Techniques and Experiments. Nineth edn. pp. 65, Nirali Prakashan, Pune.

Khatune AN, Mossadik AM, Rahman MM, Khondkar P, Haque EM. (2005) A benzofuranone from the flowers of Nyctanthes arbor-tristis Linn. and its antibacterial and cytotoxic activities. Indian J. Pharm. Sci. 4, 105-112.

Kirtikar KR, Basu BD. (1995) Indian Medicinal Plants. Vol. II. Third edn. pp. 1526, International Book Distributors, Dehradun.

Organization for Economic Co-operation and Development. (1998) OECD Guidelines for the Testing of Chemicals. OECD Guideline 425. Acute Oral Toxicity. Up-and-Down Procedure.

Orhan DD, Orhan N, Ergun E, Ergun F. (2007) Hepatoprotective effect of Vitis vinifera L. leaves on carbon tetrachloride-induced acute liver damage in rats. J. Ethnopharmacol. 112, 145-151.

Osel A, Gennaro AR, Martin AN. (1975) Remington's Pharmaceutical Science. Fifteenth edn. pp. 245, Mark Publishing Company, Pennsylvania.

Pittaya T, Rayanil K, Taylor CW. (2003) Chemical constituents from the flowers of Nyctanthes arbortristis Linn. Sci. Asia 29, 21-30.

Priya K, Ganjewala D. (2007) Antibacterial activities and phytochemical analysis of different plant parts of N. arbor-tristis Linn. J. Phytochem. 1, 61-67.

Reddy PB, Reddy CK, Rambhau D, Venkateshvaralu V, Murthy VN. (1993) Hepatoprotective activity of some Ayurvedic preparations. Indian J. Pharm. Sci. 55, 137-140.

Sasmal D, Das S, Basu SP. (2007) Phytoconstituents and therapeutic potential of Nyctanthes arbor-tristis Linn. Pharmacognosy Reviews 1 , 344-349.

Yoganarasimhan SN. (1996) Medicinal Plants of India - Karnataka. Vol. I. pp. 333, Interline Publishing Pvt. Limited, Bangalore. 